\title{
TEA WITH JILLIAN
}

\author{
Robotic reflections.
}

\section{BY BRENDA COOPER}

$\mathrm{O}$ n 25 June 2054, Technical Nurse Paul Castle brought a program he had been working on for three years into Shady Acres Nursing Home. Hed pieced it together from bits of open source available on the web and from some failed research of his own, which he had hoped to turn into a thesis project. He had tested it with crowdsourced volunteers in Thailand. He'd done it for a patient, and because memory fascinated him.

This morning started like every other. Paul arrived early and perched at his desk, which had a view of the common kitchen for his wing, the long hallway between rooms, and of images from every room in the building. He did this just to watch the most beautiful of the robots in all of Shady Acres prepare Jillian's breakfast. She worked with precision - like all robots - never spilling a drop of the oatmeal, adding exactly the same number of raisins and the same amount of sugar. The robot stirred in a half a cup of milk the same way every morning, and added the appropriate sprinkle of tasteless vitamin powder. Then she poured a glass of faux orange juice and glided down the hallway from the common kitchen to Jillian's suite.

That was the moment Paul thought of as his meditation, his reminder to be as precise as Jillian's robot nurse, as beautiful as he could manage in every interaction with the staff and residents.

There were other robots, of course. Some looked like people. Other residents chose the cheaper and more mechanical option of wheeled bots with screens or air-displays on them and metallic arms and hands for dispensing medications, making food and helping with bedding. These often ended up decorated; his favourite had stuffed golden retrievers tied to the large central post so their heads and ears flopped around as the robot negotiated stairs or tight turns. That one belonged to Patrice Mallo, who had been a good enough dog breeder that she could afford a single-room suite. For her part, Jillian dressed her caretaker in scarves and hats and gloves, and sometimes in evening gowns. On the morning of the 25th, Jillian had dressed her robot in pink.

Jillian owned the Penthouse. She had inherited a great pile of money from a grandfather, but she'd lost her ability to do more than shuffle the halls, and now she needed help cooking and cleaning and - on some days - remembering her name.

Jillian was the loneliest person Paul had ever met. He stood in for family on visiting days, and spent 20 minutes with her and the robot and Jillian's robotic dog every afternoon at the end of his shift. He had a real dog, and parents to go home to, but just like his day started with Jillian's breakfast, it ended with her cup of tea.

The robot girl would bring in the tea, leaning down and setting the lacquer tray precisely between them. They talked over this tea, small talk about the weather, about Paul's dog Maximus whom he picked up at the end of every day and walked through Central Park. Sometimes they talked about Jillian's past, and when this made Jillian cry, Paul would dry her eyes and ask her why. The most common answer was: "I miss being home. I miss being young and spry and beautiful."

On 25 June, Paul spilled his tea on the table, so that some of the hot liquid splashed Jillian across the shoulder. This gave him an excuse to slip the data pearl from her necklace as he dried it off and add his program to her interface jewellery.

It took two days before he began to see results. The first thing he noticed was a change in the way the robot walked. Her hips slid right and left as she walked. It wasn't quite feminine, but neither was it robotic. He imagined Jillian walking that way when she looked like a fully fleshed version of her metal companion. The idea made him smile.

At tea that day, Jillian looked happier. Her hands still shook as she held her china cup, her orange lipstick still missed the corners of her mouth, and her thin hair still clung to her cheeks. But her eyes were brighter and she gave him a smile that he imagined was just a touch more aware.

Weeks passed.

The robot began to join them for tea, to talk to Jillian about her past in a soft, silky $\rightarrow$ NATURE.COM

Follow Futures on Facebook at: go.nature.com/mtoodm and metallic voice. The two spent more time together. They bent their heads over books. The robot girl watched vids with the old woman, so close that metal touched skin often enough that Paul had to $\stackrel{ }{5}$ powder the old woman's legs so she wouldn't be burned by the friction of the robot's movements. Jillian even named the robot after herself, calling her Jilly.

Over tea, Paul spoke softly. "Does it help you when Jilly can keep your memories for you?"

"Yes." She paused. "I like it that when I talk to her she can recall the way the garden smelled after one of Poppa's parties."
"Are you happier?"

"Yes thank you. I know you helped to do that."

He hadn't expected that. "How?"

"Jilly told me. She remembers the day you spilled the tea, and how it felt to have the interface gone and returned, and how more kinds of things I want to tell her get stuck in her head so she can take them out for me later. She says you have made her into my mirror." Jillian took a sip, age-spotted hands shaking so the liquid almost spilled from the cup. "Thank you."

Brenda Cooper's latest novel is Mayan December, available from Prime Books. Brenda lives in the United States in a family that includes as many dogs as people. See www.brenda-cooper.com for more information. 